a stem nearly $3 / 4$ the length of the cylindric basal enlargement, which latter has a length atout twice its diameter; terminal segment produced, the basal enlargement cylindric, with a length more than three times its diameter and apically a finger-like process. Palpi: first segment subquadrate, with a length more than twice its diameter, the second twice the length of the first, the third a little longer, somewhat dilated; the fourth a little longer and more slender than the third. Mesorotum slaty brown, the submedian lines indistinct. Scutellum yellowish, fostscutellum fuscous yellowish. Abdomen brownish red, the dorsal sclerites somewhat fuscous. Ovipasitor reddish yel!ow. Halteres yellowish transparent, fuscous subapically. Coxæ pale yellowish, ferora light straw, tibiæ and tarsi fuscous straw. Ovifcsitor stout, nearly as long as the abdomen, the terminal lobes lanccolate, sparsely setose. Type, Cecid a 2411.

Described from a number of males and females taken together and presumably specifically identical.

\title{
A NEW SPECIES OF HELIOTHRIPS (THYSANOPTERA) FROM MARYLAND AND ILLINOIS.
}

BY $\mathbf{j}$. DOUGLAS HOOD,

United States Biological Survey, Washington, D. C.

The systematist's interest in the genus Heliothrips Haliday is enhanced by the fact that it includes several of the best krown and most troublesome species of the order. Hamorrhoidalis and femoralis are cosmopolitan greenhouse pests ; rubrocinctus, a widely distributed tropical species, injurious to cacao, has lately appeared in Florida as an enemy of the mango and avocado; fasciatus often proves troublescme to keans and cther crops in California ; while the recently described phaséoli is an imfortant bean pest in southernmost Texas.

In a recent paper on the genus, ${ }^{*}$ Dr. Karny unites Dictyothrips and Parthenothrips with Heliothrips, recognizing them as subgerera only, and erects a fourth subgenus, Selenothrips, for a new species which he calls decolor and for rubrocinctus Giard. While admitting that Selenothrips is a well-founded subgenus, I can rot follow Dr. Karny in his treatment of Dictyothrips and Parthenothrips. In the

*Revision der Gattung Heliothrips Haliday, Ent. Rundsch., 28 Jhg., no. 23, pp. 179-182, 5 figs.; 1911.

September, 1913 
sinking of the former, Dr. Karny was led into error by Dr. Hinds' description of Heliothrips fasciatus Pergande, ** in which the number of segments in the maxillary palpi is erroneously given as three, instead of two-a mistake which was copied also by Moulton.*** Dictyothrips is thus readily separable by the three-segmented maxillary palpi; while the number of antennal segments and the decidedly anomalous character of the fore wings marks Parthenothrips, in my opinion, as one of the most distinct genera of the entire family.

The new species described below is the tenth one of the genus to be recorded from North America; and as the entomological fauna of the tropical and sub-tropical south becomes better known, this number will doubtless be greatly increased.

Heliothrips striatus, sp. nov.-Figs. 11 and 12.

Female.-Length about $1.1 \mathrm{~mm}$. General color, dark blackish brown (nearly black); head and thorax paler than abdomen, the former with a yellow spot each side of the ocelli; legs dark brown, with the femora and tibiæ paler at extremities; tarsi pale; abdomen slightly paler at tip.

Head about 1.6 times as wide as long and about equal in length to prothorax; cheeks rounded to eyes, narrowed to base; dorsal

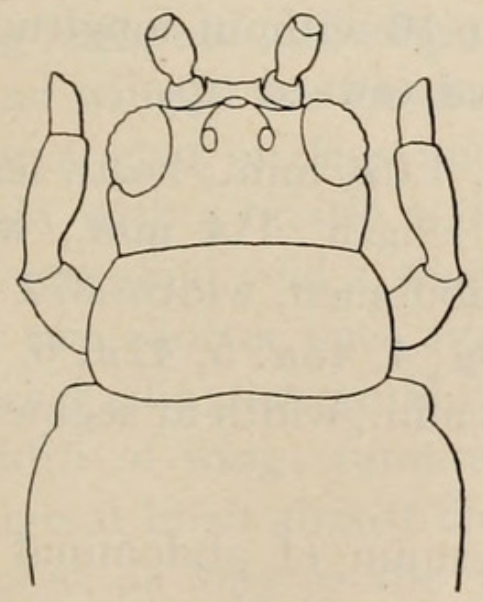

FIG. 11.-Head and prothorax.

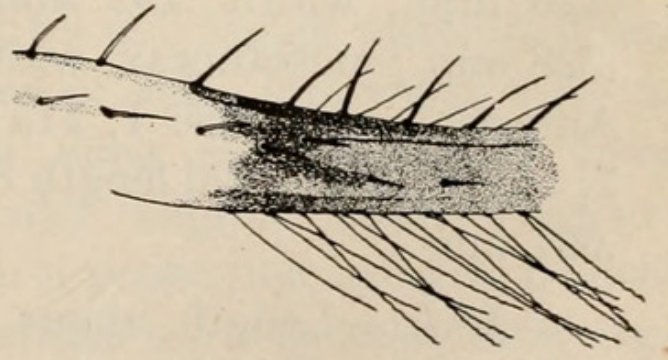

FIG. 12.-Portion of fore wing.

Heliothrips striatus Hood.

surface reticulate, roughened between the lines of reticulation; frontal costa broad, much wider than first antennal segment; vertex 
subcarinate in front of ocelli. Eyes less than twice as long as their distance from posterior margin of head, slightly protruding, setose. Ocelli approximate, the posterior pair opposite center of eyes. Antennæ about 2.3 times as long as head; segments 1 and 2 light brown; 3 , dark gray, paler in second fifth; 4 , dark gray, pale in basal half; 5 , pale grayish white, slightly darker apically; $6-8$, dark gray. Maxillary palpi two segmented.

Prothorax twice as wide as long, about equal in length to head and with similar reticulation. Pterothorax somewhat broader than prothorax, dark brown in color. Wings long, surpassing the abdomen; fore wing about thirteen times as long as width at middle and with two veins nearly or quite attaining tip; basal vein with four spines, of which the distal is much stouter, black, and situated at the fork (see figure 12); anterior vein usually with one spine (rarely two) at base and two near apex of wing, all black, the basal one unusually stout; posterior vein with five or six equidistant spines at middle, of which three or four are black; fore wings slightly darkened with brown at extreme base, clear white in basal fourth, nearly black in second and third fourths (darkest toward base), clear white again in seventh eighth, and nearly black again in apical eighth, where it is margined with darker.

Abdomen broadly ovate, pointed at tip; notum of segments 1-8 closely striate laterally, the striæ transverse toward middle of segment and longitudinal at sides. Segment 10 without longitudinal dorsal suture, though irregularly weakened toward tip.

Measurements of holotype: Length, $1.07 \mathrm{~mm}$; head, length $.120 \mathrm{~mm}$., width $.192 \mathrm{~mm}$.; prothorax, length $.114 \mathrm{~mm}$., width $.228 \mathrm{~mm}$.; mesothorax, width $.324 \mathrm{~mm}$.; abdomen, width $.372 \mathrm{~mm}$. Antennal segments: $1,21 \mu ; 2,45 \mu ; 3,50 \mu ; 4,45 \mu ; 5,41 \mu ; 6,32 \mu$; $7,15 \mu ; 8,34 \mu$; total length of antenna, . $28 \mathrm{~mm}$., width at segment 4 , $.027 \mathrm{~mm}$.

Male.-Length about $.84 \mathrm{~mm}$. Sternum of abdominal segments 3-7 each, with a large, pale, transyerse area about nine times as wide as long. Segment 9 with two pairs of dorsal spines, of which the basal is much shorter and stouter than the apical.

**Proc. U. S. Nat. Mus., vol. XXXVI, p. 174; 1902.

***Tech. Ser. 21, Bur. Ent., U. S. Dept. Agr., p. $14 ; 1911$. 
Measurements of allotype: Length $.84 \mathrm{~mm}$; head, length .102 mm., width $.168 \mathrm{~mm}$.; prothorax, length $.090 \mathrm{~mm}$., width $.196 \mathrm{~mm}$.; mesothorax, width $.252 \mathrm{~mm}$; abdomen, width $.228 \mathrm{~mm}$.

Described from three females and one male, taken near Chevy Chase Lake, Maryland, July 6, 1913, by W. L. McAtee, on the under surface of leaves of a tulip tree (Liriodendron tulipifera L.); and from one female collected at Parker, Illinois, July 14, 1909, by C. A. Hart, on the same food plant.

\section{Type locality: Chevy Chase Lake, Maryland.}

The abdominal sculpture is almost identical with that of $H$. phaseoli, figured by the writer in Psyche, Vol. xix, No. 4, plate 8, fig. c, August, 1912. From that species it may be known by the broader head, the much darker color of the body, the details of wing coloration, and the stout black spines on the fore wings at the junction of the two principal veins.

\section{ANOTHER RED SPECIES OF THE GENUS OLIGOSITA.}

\section{BY J. C. CRAWFORD, WASHINGTON, D. C.}

Oligosita giraulti, new species.

Female.-Length about $0.5 \mathrm{~mm}$. Brilliant vermilion, including marginal and stigmal veins of fore wings and marginal vein of hind wings; the femora and hind tibiæ red, the red color decreasing apicad on legs and the rest of legs testaceous; submarginal vein with a bristle at middle, and one at apex of vein, near base of marginal vein a short one followed by two longer ones, then one or two shorter ones and a long at apex of vein, fore wings with no discal cilia; marginal cilia at apex of wing slightly longer than width of wing; fumated spot in under stigmal knob distinct; stigmal knob almost circular but with a projection apicad; pedicel about as long as the funicle joint, about as long as middle segment of club which is longer than either the first or third joints; base of abdomen with a whittish band, more or less suffused with reddish and occupying about one-fourth of the abdomen.

Type locality: St. Clair Experiment Station, Trinidad. 


\section{$2 \mathrm{BHL}$ Biodiversity Heritage Library}

1913. "A new species of Heliothrips (Thysanoptera) from Maryland and Illinois." The Canadian entomologist 45, 308-311.

https://doi.org/10.4039/Ent45308-9.

View This Item Online: https://www.biodiversitylibrary.org/item/22231

DOI: https://doi.org/10.4039/Ent45308-9

Permalink: https://www.biodiversitylibrary.org/partpdf/27104

\section{Holding Institution}

MBLWHOI Library

Sponsored by

MBLWHOI Library

\section{Copyright \& Reuse}

Copyright Status: NOT_IN_COPYRIGHT

This document was created from content at the Biodiversity Heritage Library, the world's largest open access digital library for biodiversity literature and archives. Visit BHL at https://www.biodiversitylibrary.org. 